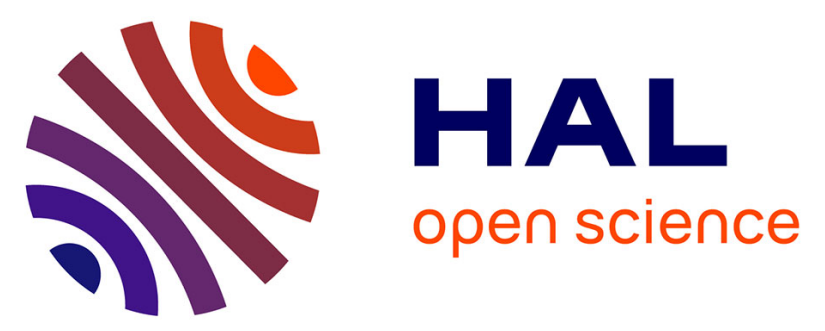

\title{
Dependence of the interaction mechanisms between l-serine and O-phospho-l-serine with calcium hydroxyapatite and copper modified hydroxyapatite in relation with the acidity of aqueous medium
}

Kaia Tõnsuaadu, Michel Gruselle, Frieda Kriisa, Andres Trikkel, Patrick Gredin, Didier Villemin

\section{To cite this version:}

Kaia Tõnsuaadu, Michel Gruselle, Frieda Kriisa, Andres Trikkel, Patrick Gredin, et al.. Dependence of the interaction mechanisms between l-serine and O-phospho-l-serine with calcium hydroxyapatite and copper modified hydroxyapatite in relation with the acidity of aqueous medium. Journal of Biological Inorganic Chemistry, 2018, pp.1-9. 10.1007/s00775-018-1594-0 . hal-01845481

\section{HAL Id: hal-01845481 \\ https://hal.sorbonne-universite.fr/hal-01845481}

Submitted on 20 Jul 2018

HAL is a multi-disciplinary open access archive for the deposit and dissemination of scientific research documents, whether they are published or not. The documents may come from teaching and research institutions in France or abroad, or from public or private research centers.
L'archive ouverte pluridisciplinaire HAL, est destinée au dépôt et à la diffusion de documents scientifiques de niveau recherche, publiés ou non, émanant des établissements d'enseignement et de recherche français ou étrangers, des laboratoires publics ou privés. 


\title{
Dependence of the interaction mechanisms between
}

\section{L-serine and O- phospho-L-serine with calcium \\ hydroxyapatite and copper modified hydroxyapatite in relation with the acidity of aqueous medium}

\author{
Kaia Tõnsuaadu $\bigotimes^{1}$, Michel Gruselle ${ }^{2,3}$, Frieda Kriisa ${ }^{1}$, Andres Trikkel ${ }^{1}$, Patrick Gredin ${ }^{3,4}$ and \\ Didier Villemin $^{5}$ \\ ${ }^{1}$ Institute of Materials and Environmental Technology, Tallinn University of Technology, \\ Ehitajate tee 5, 19086 Tallinn, Estonia
}

${ }^{2}$ CNRS, UMR 8232, Institut Parisien de Chimie Moléculaire, 4 place Jussieu, F-75005 Paris, France

${ }^{3}$ Sorbonne Université, UPMC Université Paris 06, 4 place Jussieu, F-75005 Paris, France

${ }^{4}$ Chimie Paris Tech, PSL Research Université, CNRS, Institut de Recherche de Chimie Paris, F75005 Paris, France

${ }^{5}$ LCTM, UMR 6507, ENSICAEN, INC3M, Fr 3038, Normandie Université, 14050 Caen, France

$\bowtie$ kaia.tonsuaadu@ttu.ee; Fax: 3726202801 


\begin{abstract}
ABBREVIATIONS
HAp, hydroxyapatite; CaHAp, calcium- hydroxyapatite; CuHAp, copper-substituted hydroxyapatite; L-Ser, L-serine; O-Ph-L-Ser, O-phospho-L-serine; TA, thermal analysis.
\end{abstract}

ABSTRACT Motivated by the role of copper ions in biological processes the aim of this study was to elucidate the impact of copper ions bound to hydroxyapatite on L-Serine (L-Ser) and Ophospho-L-serine (O-Ph-L-Ser) adsorption at different acidity of aqueous solutions. The adsorption phenomenon was studied by FTIR, UV, and AA spectroscopy, XRD and thermal analysis methods together with the evolved gases analysis taking into consideration the ionic state of the amino acids as well as the apatite surface state, which are tightly correlated with the solution $\mathrm{pH}$. In acidic solution, the main process involves apatite dissolution releasing calcium and copper ions. At $\mathrm{pH}>5$ the complexation of amino acids with $\mathrm{Ca}^{2+}$ or $\mathrm{Cu}^{2+}$ ions is more important leading also to the release of cations. The ability of copper ions to form water soluble complexes with L-Ser and O-Ph-L-Ser leads to an important loss of these ions, while calcium release is very low at this $\mathrm{pH}$. Therefore, the use of copper ions substituting calcium in the apatite structure to enhance the ability of amino acids adsorption on the apatite surface seems problematic even at $\mathrm{pH}>5$.

KEYWORDS Calcium hydroxyapatite; Copper modified hydroxyapatite; L-Serine; O-phosphoL-serine; adsorption 


\section{Introduction}

Hybrid organic-inorganic materials are of first importance in biological processes. Due to the role of apatites in the growth of human bones and teeth and in drug delivery, there is an increasing interest in studies related to the interactions between amino-acids and calcium apatites. Many works are devoted to the adsorption of organic and bioorganic molecules on the surface of apatites [1-5]. In general, these experiments, carried out at $\mathrm{pH}$ higher than 6 , point out the fact that apatite surface is not fundamentally modified during the adsorption process, specifically, release of mineral ions like calcium or phosphate ions from the apatite structure are not taken into consideration in the interactions. Therefore, the role of bioorganic molecules, in particular, amino-acids (AA) as reagents to change composition of the mineral support, is neglected.

Particular interest among other AA has been paid on L-Serine (L-Ser) and O-phospho-L-serine (O-Ph-L-Ser) adsorption, which were characterized by Langmuir-type adsorption on apatite [610]. The studies carried out at $\mathrm{pH} 7-10$ with L-Ser led to the conclusion that L-Ser adsorbs on the surface of hydroxyapatite (HAp) through electrostatic attractions exerted between one negative site of the HAp surface, i.e., phosphate or hydroxyl ion, and the positively charged protonated amino group of one Ser molecule, forming an ion pair surface complex [6,7].

O-Ph-L-Ser has higher affinity for the HAp surface compared to L-Ser molecules [7]. The enhanced adsorption capacity noted for O-Ph-L-Ser might be related to the presence of phosphate groups in the molecule, which are potential specific attachment sites. The monoprotonated negatively charged $\left(\mathrm{HL}^{2-}\right) \mathrm{O}-\mathrm{Ph}-\mathrm{L}-\mathrm{Ser}$ species were found adsorbed forming surface complexes with the positively charged $\equiv \mathrm{CaOH}^{2+}$ sites on the surface of HAp at $\mathrm{pH} 7$ [8]. The negatively charged deprotonated carboxyl and phosphate groups of the adsorbed $\mathrm{HL}^{2-}$ species 
orient themselves at the maximum possible distance from the negatively charged surface of HAp because of electrostatic repulsions [9].

The only study performed in acidic O-Ph-L-Ser solutions [10] concluded that there occurs an ion-exchange between HAp and P-Ser in dilute solutions. The dissolution of apatite released phosphate and calcium ions into the solution in the amounts linearly related to the uptake of serine ( $<8 \mathrm{mM}$ solution).

Taking into consideration that the drug delivery process is strongly influenced by the acidity of the biological medium, we decided to revisit the mechanisms of the adsorption of AA, namely LSerine and O- Phospho-L-serine, shown in Fig. 1, with Ca-hydroxyapatite (CaHAp) and a copper modified Ca-hydroxyapatite (CuHAp) in relation with the acidity of the aqueous medium from acidic to smoothly basic one. The use of calcium apatites doped with copper ions is interesting to show the specific role that oxidation state II ions can play in sorption mechanism of AA. The question is therefore whether these ions will increase the ability of apatite to adsorb amino acids on the apatitic surface and by what mechanism. We first chose copper ions for their known role in biological and catalytic processes [11-13].
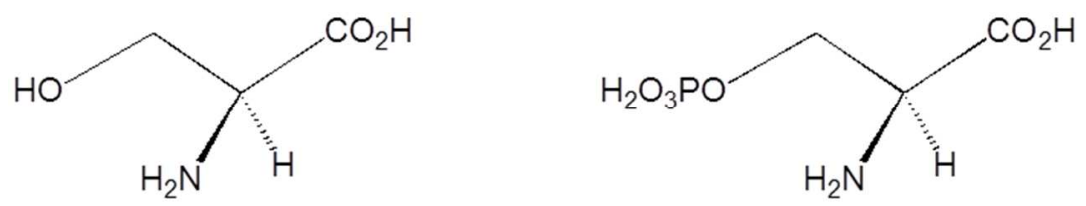

Fig. 1. L-Serine (left); O- Phospho-L-serine (right).

\section{Experimental Section}

\subsection{Synthesis of CaHAp and CuHAp}

The chemicals used for synthesis of apatites were of ACS grade, purchased from SigmaAldrich, Merck KGaA and Acros. The CaHAp was synthesized by precipitation in aqueous 
solution using a PC-controlled LARA reactor system (Radleys) in deionized $\mathrm{CO}_{2}$-free water at $25^{\circ} \mathrm{C}$ in $\mathrm{N}_{2}$ atmosphere keeping $\mathrm{pH}=9$ by continuous addition of ammonia solution and keeping $\mathrm{Ca} / \mathrm{P}$ mole ratio equal to 1.67 . The $\mathrm{Ca}\left(\mathrm{NO}_{3}\right)_{2}(0.5 \mathrm{M})$ and $\mathrm{NH}_{4} \mathrm{H}_{2} \mathrm{PO}_{4}(0.3 \mathrm{M})$ solutions were added simultaneously into $\mathrm{NH}_{4} \mathrm{OH}$ aqueous solution $(0.5 \mathrm{~L})$. The obtained suspension was stirred for 1 hour and matured for 24 hours at room temperature. The precipitate was filtered, washed several times with deionized $\mathrm{CO}_{2}$-free water and lyophilized. The $\mathrm{Cu}$ substituted apatite was obtained mixing the washed CaHAp slurry in $\mathrm{Cu}$-acetate solution $(0.01 \mathrm{M})$ for 3 hours, after that filtrated, washed and lyophilized.

\subsection{Sorption experiments}

L-Ser and O-Ph-L-Ser sorption experiments were performed with AA solutions in the range of 0.005 to $0.05 \mathrm{M}$ in the $\mathrm{pH}$ interval from 2 to 8 , adjusted by addition of $0.01 \mathrm{M} \mathrm{KOH}$ or $0.01 \mathrm{M}$ $\mathrm{HNO}_{3}$ solution using automate titrator Mettler Toledo T90 with pH electrode DG-112 Pro. The accuracy was \pm 0.02 . The initial $\mathrm{pH}$ values were chosen according to the $\mathrm{O}-\mathrm{Ph}-\mathrm{L}-\mathrm{Ser}$ solution titration curve.

Apatite, $300 \mathrm{mg}$, was added to $50 \mathrm{ml}$ of AA solution, mixed in centrifugal tube at overhead mixer for 100 min and centrifuged. The experiments were performed in triplicate and the results were averaged. After separation of the solid and liquid phases, $\mathrm{pH}$ and the cations content were determined in the solution and the UV spectrum was recorded. The solid residue was dried at 60 ${ }^{\circ} \mathrm{C}$ and then subjected to XRD, FTIR and thermal analysis.

\subsection{Analytical methods}


XRD patterns were recorded with an INEL Equinox 1000 diffractometer operating in real time acquisition over $2 \theta$ range $5-115^{\circ}$ in asymmetric mode. The diffractometer is equipped with a cobalt anode and a primary graphite monochromator $\left(\lambda_{\mathrm{K \alpha} 1}=1.7889 \AA, \lambda_{\mathrm{K \alpha} 2}=1.7928 \AA\right)$. The $2 \theta$ angular resolution is 0.029 . The cell dimensions and average crystallite size were determined by FULLPROF program [14].

FTIR spectra were recorded with a Bruker 55/S/NIR FTIR ATR spectrometer as an average of 30 scans at resolution $4 \mathrm{~cm}^{-1}$.

The simultaneous TG/DTA/EGA-MS measurements were performed in an apparatus consisting of a LabSys-Evo 1600 (Setaram, France) thermal analyzer and an OmniStar (Pfeiffer, Germany) Quadrupole mass spectrometer. Coupling between the two components was provided through a heated capillary tube kept at $\mathrm{T}=180^{\circ} \mathrm{C}$. The ion currents of the selected mass/charge $(\mathrm{m} / \mathrm{z})$ numbers were monitored in multiple ion detection (MID) mode (Quadera version 4.20 software) with the collection time of $1 \mathrm{~s}$ for each channel. The measurement was carried out in Ar- $\mathrm{O}_{2}(20 \%)$ mixture atmosphere in the temperature range of $30-1000^{\circ} \mathrm{C}$ using the heating rate of $10 \mathrm{deg} \cdot \mathrm{min}^{-1}$, the gas flow rate of $60 \mathrm{~mL} \cdot \mathrm{min}^{-1}$ and open Pt crucibles. The initial mass of sample was 25-35 mg. The MS mass-to-charge ratios (m/z) selected for analysis were 15 for $\mathrm{NH}_{3}$ to avoid the overlapping with $\mathrm{H}_{2} \mathrm{O}, 18$ for $\mathrm{H}_{2} \mathrm{O}, 30$ for $\mathrm{NO}_{\mathrm{x}}$ (sum of $\mathrm{NO}, \mathrm{N}_{2} \mathrm{O}$ and $\mathrm{NO}_{2}$ ) and 44 amu for $\mathrm{CO}_{2}$.

UV absorption spectra of the solutions in deionized water were recorded with Biochrom Libras 70PC UV/Visible Spectrophotometer in the wavelength interval from 190 to $400 \mathrm{~nm}$ with step 2 $\mathrm{nm}$ in quartz cuvettes of $10 \mathrm{~mm}$ path length using deionized water as reference.

The macro-components of the synthesis products were determined by standard analytical methods. Content of $\mathrm{Ca}$ and $\mathrm{Cu}$ was determined after dissolution of sample in diluted $\mathrm{HCl}$ by 
AAS (Varian SpectrAA 55B Flame AAS) and phosphorus by photo colorimetry method as phosphomolybdate yellow complex (Biochrom Libras 70PC UV/Visible Spectrophotometer). The error in chemical analyses was under $2 \%$.

The specific surface area (SSA) measurements were performed by BET-method (adsorptive gas $\mathrm{N}_{2}$, carrier gas $\mathrm{He}$, heating temperature $110^{\circ} \mathrm{C}$ ) using sorptometer EMS-53.

\section{Results}

\subsection{Characterization of apatites}

The XRD, FTIR and chemical analysis revealed that the materials obtained by precipitation were near-stoichiometric apatites, where cations/P mole ratio was 1.62 (Table 1, theory 1.67). XRD patterns and the unit cell parameters of the precipitated apatites, CaHAp and CuHAp, correspond well to a standard HAp (Diffraction standards ICDD card 00-055-0592) [14]. The unit cell parameters were $a=9.413$ and $9.394, c=6.860$ and $6.855 \AA( \pm 0.001 \AA)$, respectively. Decrease in unit cell parameters of CuHAp is in correlation with the smaller atomic radii of $\mathrm{Cu}$ in comparison with $\mathrm{Ca}$. The average size of particles $110( \pm 21)$ and $68( \pm 17) \mathrm{nm}$ correlates with the specific surface values 126 and $154 \mathrm{~m}^{2} / \mathrm{g}$.

Table 1. Chemical composition and specific surface area of the apatites.

\begin{tabular}{llllll}
\hline Apatite & $\begin{array}{l}(\mathrm{Ca}+\mathrm{Cu}) / \mathrm{P}, \\
\text { Mole ratio }\end{array}$ & $\begin{array}{l}\mathrm{Ca}, \\
\%\end{array}$ & $\begin{array}{l}\mathrm{P}, \\
\%\end{array}$ & $\begin{array}{l}\mathrm{Cu}, \\
\%\end{array}$ & $\begin{array}{l}\text { Specific surface area, } \\
\mathrm{m}^{2} / \mathrm{g}\end{array}$ \\
\hline CaHAp & 1.62 & 38.25 & 18.28 & 0 & 126 \\
CuHAp & 1.62 & 36.10 & 17.54 & 0.91 & 154 \\
\hline
\end{tabular}


To analyze the consequences of the interactions between the solid material and the AA solutions, the changes in the solutions $\mathrm{pH}$, the quantities of $\mathrm{Ca}$ and $\mathrm{Cu}$ ions released in the solution during contact and the chemical and structural transformations of the apatite materials were determined.

\subsection{Analysis of solutions}

\subsubsection{Change of the AA solutions $\mathrm{pH}$ after contact with CaHAp and CuHAp}

Due to various processes that occur at the solid surface/solution interface (preferential dissolution of certain constituents of crystal lattice, ionization of surface groups, adsorption of ions or formation of complex compounds between surface groups and ions from the solution), the final $\mathrm{pH}$ values differ from the initial ones.

After mixing HAp - water suspension during 100 min the final $\mathrm{pH}$ values are found as 6.46 and 6.82 for CaHAp and CuHAp, respectively. The changes of $\mathrm{pH}$ values of the L-Ser and O-PhL-Ser solutions as a result of the contact with apatite are presented in Suppl. mat. Fig. S1. The bigger change occurs at low initial $\mathrm{pH}$. The $\mathrm{pH}$ variation goes from the initial $\mathrm{pH}$ value 2 to a value greater than 4 . For L-Ser starting at $\mathrm{pH} 6$ after mixing, the $\mathrm{pH}$ values increase in all the studied cases by 0.5 to $1.25 \mathrm{pH}$ units. When the initial $\mathrm{pH}$ is 8 , after mixing, the change in all $\mathrm{pH}$ values is -0.5 to -1.0 . These trends show that the solution tends to return to the $\mathrm{pH}$ corresponding to the point of zero charge (pzc). For O-Ph-L-Ser the same trends are observed. The bigger change occurs at low $\mathrm{pH}$, the $\mathrm{pH}$ variation goes from the initial $\mathrm{pH}=2$ to a value greater than 4 .

The $\mathrm{pH}$ value changes in correlation with the $\mathrm{AA}$ concentration and initial $\mathrm{pH}$ value. The largest increase takes place at higher concentration and at initial $\mathrm{pH}<7$. The $\mathrm{pH}$ change is almost at the same level for both AA and apatites. At initial $\mathrm{pH} 8$, the decrease up to -0.9 is followed, which is more evident in L-Ser solutions. 


\subsubsection{Release of $\mathrm{Ca}^{2+}$ and $\mathrm{Cu}^{2+}$.}

The results concerning the release of $\mathrm{Ca}^{2+}$ and $\mathrm{Cu}^{2+}$ in aqueous solution when treating CaHAp and CuHAp by L-Ser or O-Ph-L-Ser are presented in Fig. S2. $\mathrm{Ca}^{2+}$ and $\mathrm{Cu}^{2+}$ release was 35 and 27 rel.\%, accordingly, in L-Ser solution at $\mathrm{pH}$ 2. In L-Ser solution at $\mathrm{pH} 6$ or 8, the Ca release is very low, especially, at $\mathrm{pH} 8$, decreasing from $0.3-0.4 \%$ at $\mathrm{pH} 6$ to $0.04-0.08 \%$ at $\mathrm{pH} 8$. The release does not depend on L-Ser concentration. In the presence of AA the apatite solubility is a little lower than in pure water at $\mathrm{pH}>6(0.12 \%)$ that is in agreement with the ability of AA to give complexes with calcium ions at the apatite surface [6]. In contrast with $\mathrm{Ca}^{2+}$ ions the release of $\mathrm{Cu}^{2+}$ ions is much higher, achieving $29.3 \%$ at $\mathrm{pH}$ 8. As a notable difference with $\mathrm{Ca}$, the $\mathrm{Cu}$ release is independent on the initial $\mathrm{pH}$ of the solution.

Substantially higher Ca release occurs in O-Ph-L-Ser solutions. As expected, due to apatite dissolution, Ca content in solutions is the highest with initial $\mathrm{pH}$ 2. Ca relative solubility in water with $\mathrm{HNO}_{3}$ was 10.61 and 12.74 rel.\% for CaHAp and CuHAp, respectively. It increases from 12.8 to 63.1 rel.\% for both apatites with the increase of AA concentration in solution from 0.01 to $0.05 \mathrm{M}$. The Ca solubility drops to $1-3$ rel.\% at $\mathrm{pH} 6$ and $0-5$ rel. $\%$ at $\mathrm{pH} 8$. The $\mathrm{Cu}$ release has a minimum at $\mathrm{pH} 6$ and the highest values at $\mathrm{pH} 2$ and 8 that is more obvious for concentrations $\geq 0.02 \mathrm{M}$. Ca release is much higher than $\mathrm{Cu}$ release at $\mathrm{pH} 2$, but above $\mathrm{pH} 6$ the $\mathrm{Cu}$ release exceeds $\mathrm{Ca}$ release. $\mathrm{Cu}$ solubility in $\mathrm{O}-\mathrm{Ph}-\mathrm{L}-\mathrm{Ser}$ solutions is a little lower than in L-Ser solutions.

\subsubsection{UV spectroscopic analysis}

Frequently, UV absorption measurements have been used for amino acid content determination in a solution [10]. Unfortunately, the shape of L-Ser and O-Ph-L-Ser absorption spectra depends not only on AA concentration but also on the content of other ions $\left(\mathrm{NO}_{3}^{-}, \mathrm{PO}_{4}{ }^{3^{-}}, \mathrm{Cu}^{2+}\right)$ and $\mathrm{pH}$ of 
the solution (see Suppl. Mat. Fig. S3-S6). Therefore, the determination of amino acid concentration by UV spectra is not reliable in the conditions when several variables as $\mathrm{pH}$ and ions concentration are changing.

However, UV spectra revealed the formation of $\mathrm{Cu}-\mathrm{AA}$ complexes in the solutions. In Fig. 2. UV spectra of L-Ser containing $0.0015 \mathrm{mg} \mathrm{Cu}$ per $1 \mathrm{ml}$ at different $\mathrm{pH}$ values (A) and the intensities of the absorption peak at $246 \mathrm{~nm}$ depending on $\mathrm{pH}$ value of $\mathrm{Cu}$-acetate, $\mathrm{L}-\mathrm{Ser}+\mathrm{Cu}-$ ac., and O-Ph-L-Ser $+\mathrm{Cu}-$ ac. solutions (B) are presented. The intensity of the peak at $246 \mathrm{~nm}$ that corresponds to $\mathrm{Cu}-\mathrm{AA}$ complex, increases equally for both $\mathrm{AA}$ up to $\mathrm{pH} 6$ and keeps this value at higher $\mathrm{pH}$. The peak intensity at $246 \mathrm{~nm}$ depends also on $\mathrm{Cu}^{2+}$ content in solution (Suppl. Mat. Fig. S3). Therefore, $\mathrm{Cu}^{2+}$ release from apatite is related to its complexation with AA.

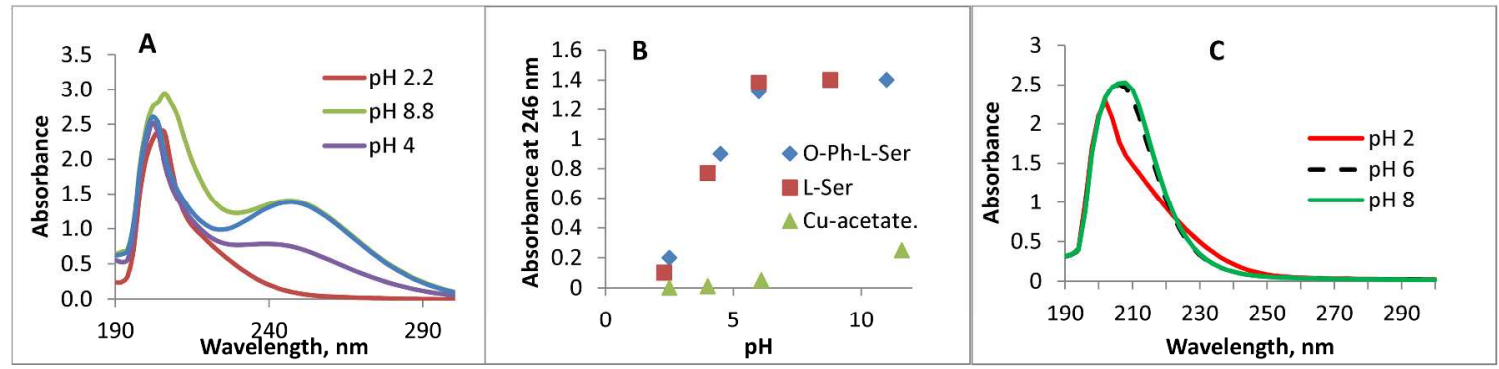

Fig. 2. A: UV spectra of $0.01 \mathrm{M} \mathrm{L-Ser}+0.0015 \mathrm{mg} \mathrm{Cu} / \mathrm{ml}$ at different $\mathrm{pH}$. B: Absorption intensity at $246 \mathrm{~nm}$ for $\mathrm{Cu}$-acetate, $\mathrm{L}-\mathrm{Ser}+\mathrm{Cu}-\mathrm{ac}$, , and $\mathrm{O}-\mathrm{Ph}-\mathrm{L}-\mathrm{Ser}+\mathrm{Cu}-\mathrm{ac}$. solutions depending on pH. C: UV spectra of 0.02 M O-Ph-L-Ser at different $\mathrm{pH}$.

\subsection{Analysis of solid residue}

3.3.1. XRD 
The XRD analysis was performed for the samples treated with $0.02 \mathrm{M}$ L-Ser and O-Ph-L-Ser solutions. The results obtained from XRD patterns are presented in Suppl. Mat. Table S1.

The change of unit cell parameters as a result of interaction with L-Ser and O-Ph-L-Ser solutions indicates the small changes in apatite crystal structure. Due to the reaction with L-Ser, both unit cell parameters $a$ and $c$ increase while cell parameters of apatite remain almost unchanged or decrease very slightly by interaction with O-Ph-L-Ser. Actually, these changes are too small to be correctly interpreted.

\subsubsection{FTIR spectroscopy}

Comparison of the spectra recorded before and after amino acid sorption experiments reveals very small changes in the apatite spectra. These spectra are shown in Figures 3 and 4. However, some differences are found at wavelength intervals of $700-850$ and $1300-1700 \mathrm{~cm}^{-1}$.

In the spectrum of a mechanical mixture of CaHAp and L-Ser (5\%) the characteristic absorptions of L-Ser and apatite are found at the same wavelength values that in the pure forms: at $1586 \mathrm{~cm}^{-1}$ for $\mathrm{CO}_{2}^{-}\left(v_{\mathrm{as}}\right)$, at $1417 \mathrm{~cm}^{-1}$ for $\mathrm{CO}_{2}^{-}\left(v_{\mathrm{s}}\right)$, at $1600 \mathrm{~cm}^{-1}$ for $\mathrm{COO}^{-}\left(v_{\mathrm{s}}\right)$, at $1464 \mathrm{~cm}^{-1}$ for $\mathrm{NH}_{3}{ }^{+}\left(v_{\mathrm{s}}\right)$, and at 1306 and $1342 \mathrm{~cm}^{-1}$ for $\mathrm{CH}$ groups vibrations [18]. In the spectra of the material resulting from the sorption of L-Ser on apatite surface, an absorption peak at $1547 \mathrm{~cm}^{-1}$ that could be assigned to $\mathrm{COO}^{-}\left(v_{\mathrm{as}}\right)$ [19] is visible. The absorption of carbonate substituted for phosphate in apatite structure [20] or of $\mathrm{NH}_{3}^{+}\left(v_{\mathrm{s}}\right)$ at $1453 \mathrm{~cm}^{-1}$ [7] is increased. A shoulder at $1630 \mathrm{~cm}^{-1}$ appears next to $\mathrm{H}_{2} \mathrm{O}$ absorption at $1641 \mathrm{~cm}^{-1}$ in apatite structure, which has been assigned to $\mathrm{COO}^{-}\left(v_{\mathrm{as}}\right)$ vibration shifted due to L-Ser adsorption on apatite [21] and absorption at $1329 \mathrm{~cm}^{-1}$ appears in spectra of samples treated at $\mathrm{pH}$ 2. These changes can be seen better for the samples of CaHAp. No impact of the solution concentration is found. 


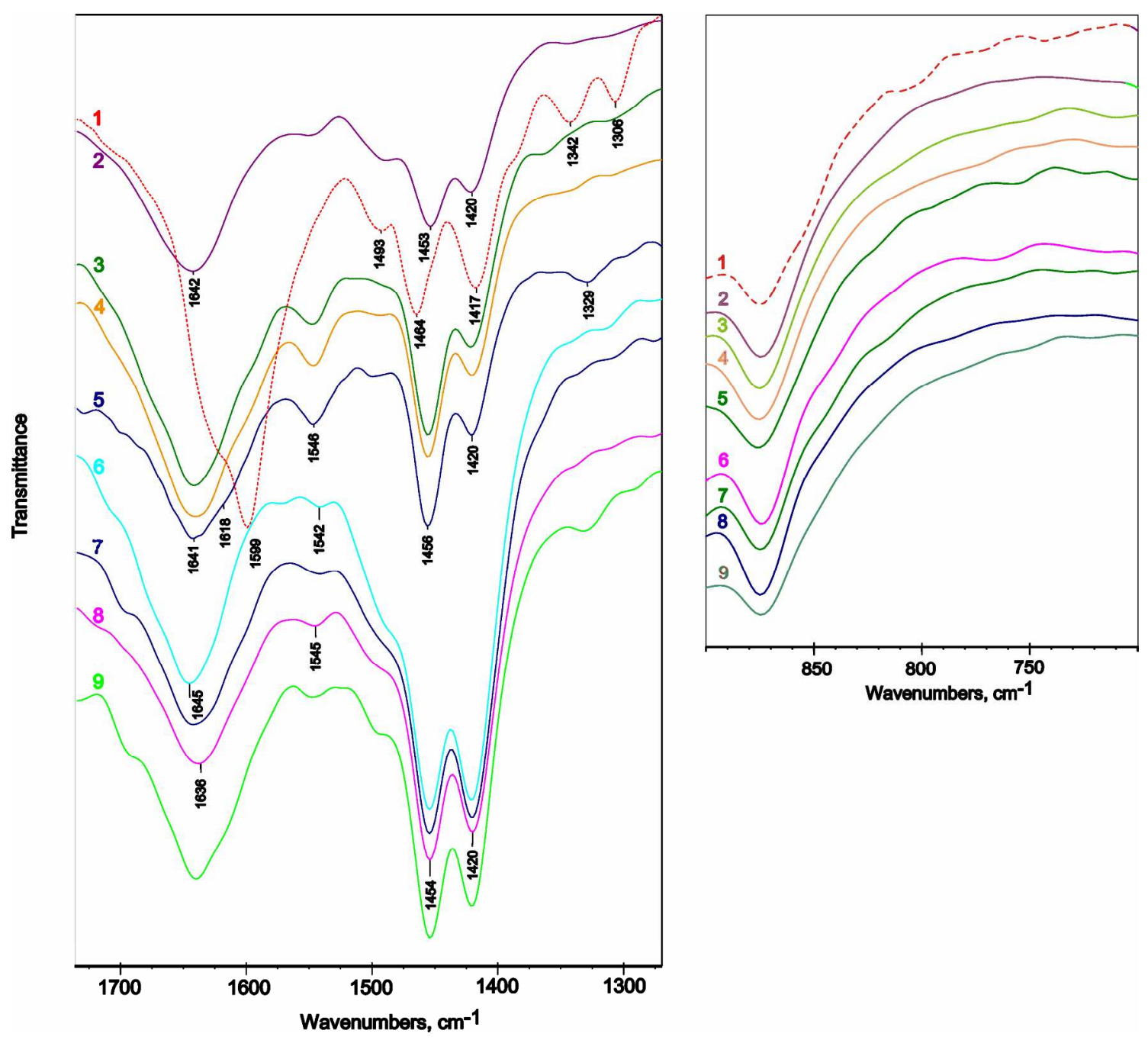

Fig. 3. FTIR spectra of CaHAp and CuHAp before and after sorption experiment in $0.02 \mathrm{M} \mathrm{L-}$ Ser solution and the mechanical mixture with 5\% L-Ser. 1-CaHAp+ 5\% L-Ser; 2- CaHAp; 3 CaHAp+L-Ser pH 8; 4 - CaHAp+L-Ser pH 6; 5 - CaHAp+ L-Ser pH 2; 6 - CuHAp; 7 CuHAp+L-Ser pH 8; 8 - CuHAp+L-Ser pH 6; 9 - CuHAp+L-Ser pH 2. 


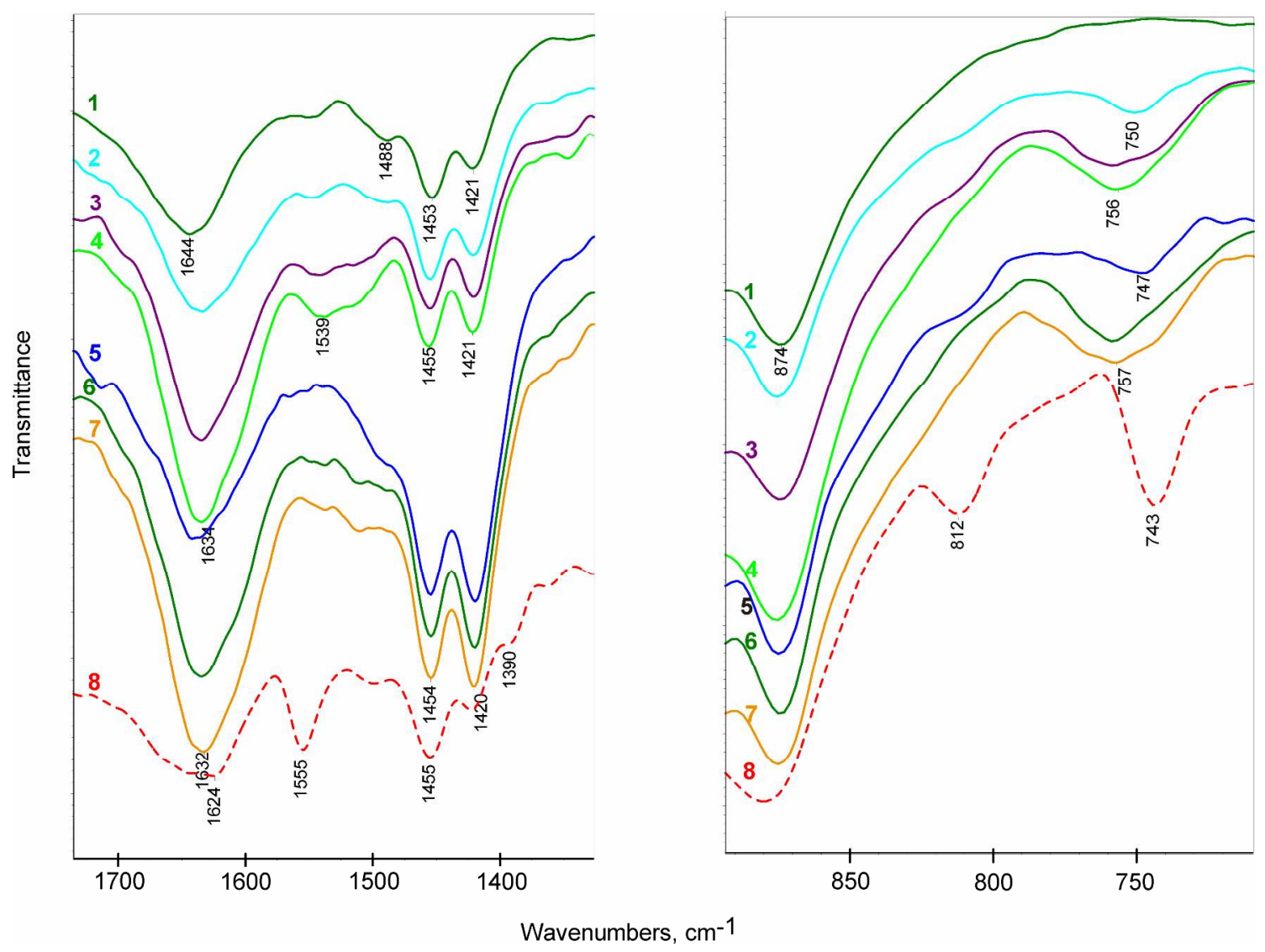

Fig. 4. FTIR spectra of CaHAp and CuHAp before and after sorption experiment in $0.02 \mathrm{M}$ OPh-L-Ser solutions and the mechanical mixture with 5\% O-Ph-L-Ser. 1 - CaHAp; 2- CaHAp+ O-Ph-L-Ser pH 8; 3 - CaHAp+ O-Ph-L-Ser pH 6; 4 - CaHAp+ O-Ph-LSer pH 2; 5- CuHAp+ O-Ph-L-Ser pH 8; 6 - CuHAp+ O-Ph-L-Ser pH 6; 7 - CuHAp+ O-Ph-LSer pH 2; 8 - CaHAp+ 5\% O-Ph-L-Ser.

In the spectrum of a mechanical mixture of CaHAp and O-Ph-L-Ser (5\%) the absorption peaks of O-Ph-L-Ser, in addition to apatite peaks, are found at 1638, 1624, 1555, 1390, 1256, 812,745 and $495 \mathrm{~cm}^{-1}$. Changes in the spectra of CaHAp and CuHAp used for sorption of O-PhL-Ser differ from these caused by L-Ser adsorption. The new weak peaks at 1540 and $1516 \mathrm{~cm}^{-1}$, particularly after reaction at $\mathrm{pH} \mathrm{2,} \mathrm{and} \mathrm{the} \mathrm{increase} \mathrm{in} \mathrm{peak} \mathrm{intensity} \mathrm{at} 1420 \mathrm{~cm}^{-1}$, related to 
$\mathrm{COO}^{-}\left(v_{\mathrm{s}}\right)$ vibration [7,19], are followed in the spectra of O-Ph-L-Ser treated apatites. Additionally, to the changes in the spectral region of $1300-1700 \mathrm{~cm}^{-1}$, the peak at $745 \mathrm{~cm}^{-1}$, assigned to P-C $\left(v_{\mathrm{s}}\right)$ [22], is shifted up to $762 \mathrm{~cm}^{-1}$ depending on the final $\mathrm{pH}$ of the solution. This peak intensity increases together with the O-Ph-L-Ser concentration and decrease in the initial $\mathrm{pH}$ increase of the solution, similarly, to Ca release. The absorption peaks related to $\mathrm{NH}_{3}{ }^{+}$ vibrations are less intensive but the changes related to $\mathrm{COO}^{-}$vibration intensities are more visible.

\subsubsection{Thermal analysis}

The thermal analysis (thermogravimetric analysis together with thermal changes and evolved gas analyses) were performed with the aim to prove the adsorption of AA on apatite and also to evaluate the amount of AA bound. The amount of organic matter in a solid sample was determined from the amount of $\mathrm{NO}_{\mathrm{x}}$ gases evolved at calcination detected by MS analysis. The peak area under the $\mathrm{NO}_{\mathrm{x}}$ evolvement curve was measured and the normalized value was used as an indicator of the amino acid content in the sample.

The mechanical mixtures of apatite and O-Ph-L-Ser or L-Ser with 3 and 5 mass \% in it were prepared for estimating the $\mathrm{NO}_{\mathrm{x}}$ amount released at calcination from sorption experiment samples. The results of TA are given in Figures 5 - 7. TA clearly exhibits the adsorption of L-Ser and $\mathrm{O}-\mathrm{Ph}-\mathrm{L}-\mathrm{Ser}$ on apatite by an exothermic effect with the maximum in the interval of 200-300 ${ }^{\circ} \mathrm{C}$ caused by the oxidation reaction of organic matter. In addition, the mass loss and the amount of $\mathrm{CO}_{2}$ and $\mathrm{NO}_{\mathrm{x}}$ released, increases in comparison with the pure apatites (Fig. 5). The profile of the curves changes together with the variation in the solution $\mathrm{pH}$ used (Fig. 6), indicating to different sorption mechanism at different $\mathrm{pH}$. The amount of $\mathrm{NO}_{\mathrm{x}}$ evolved increases with the 
increase in AA solution concentration and decreases with the increase in $\mathrm{pH}$ (Fig. 7). By TA results the amount of AA adsorbed on CuHAp is almost the same as on CaHAp.

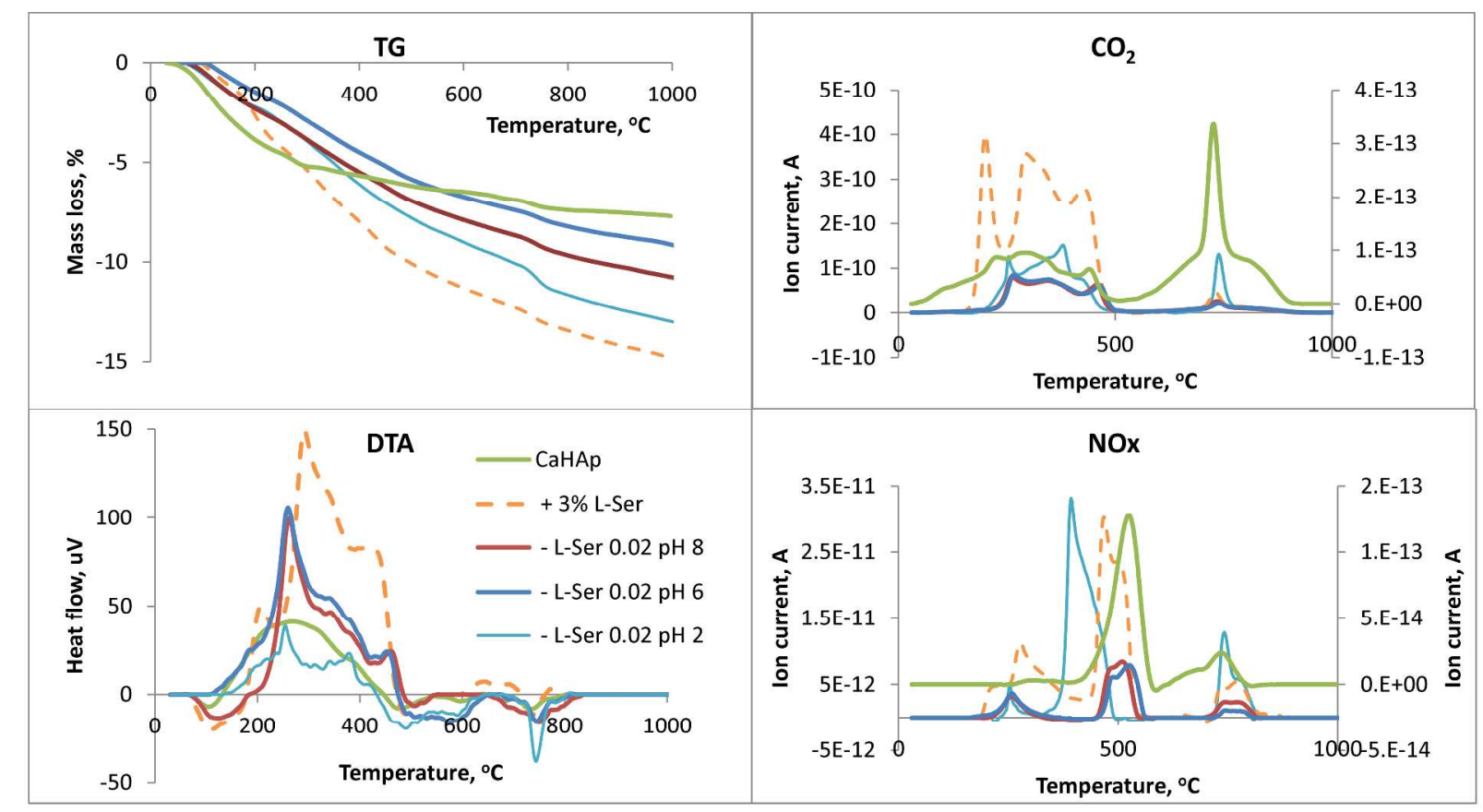

Fig. 5. Mass loss, DTA, $\mathrm{CO}_{2}$ and $\mathrm{NO}_{\mathrm{x}}$ evolvement profile curves of CaHAp, mixture of CaHAp+3\% L-Ser and the samples after sorption experiment in $0.02 \mathrm{M} \mathrm{L-Ser} \mathrm{solutions} \mathrm{at} \mathrm{pH} 2$, 6 and 8. 


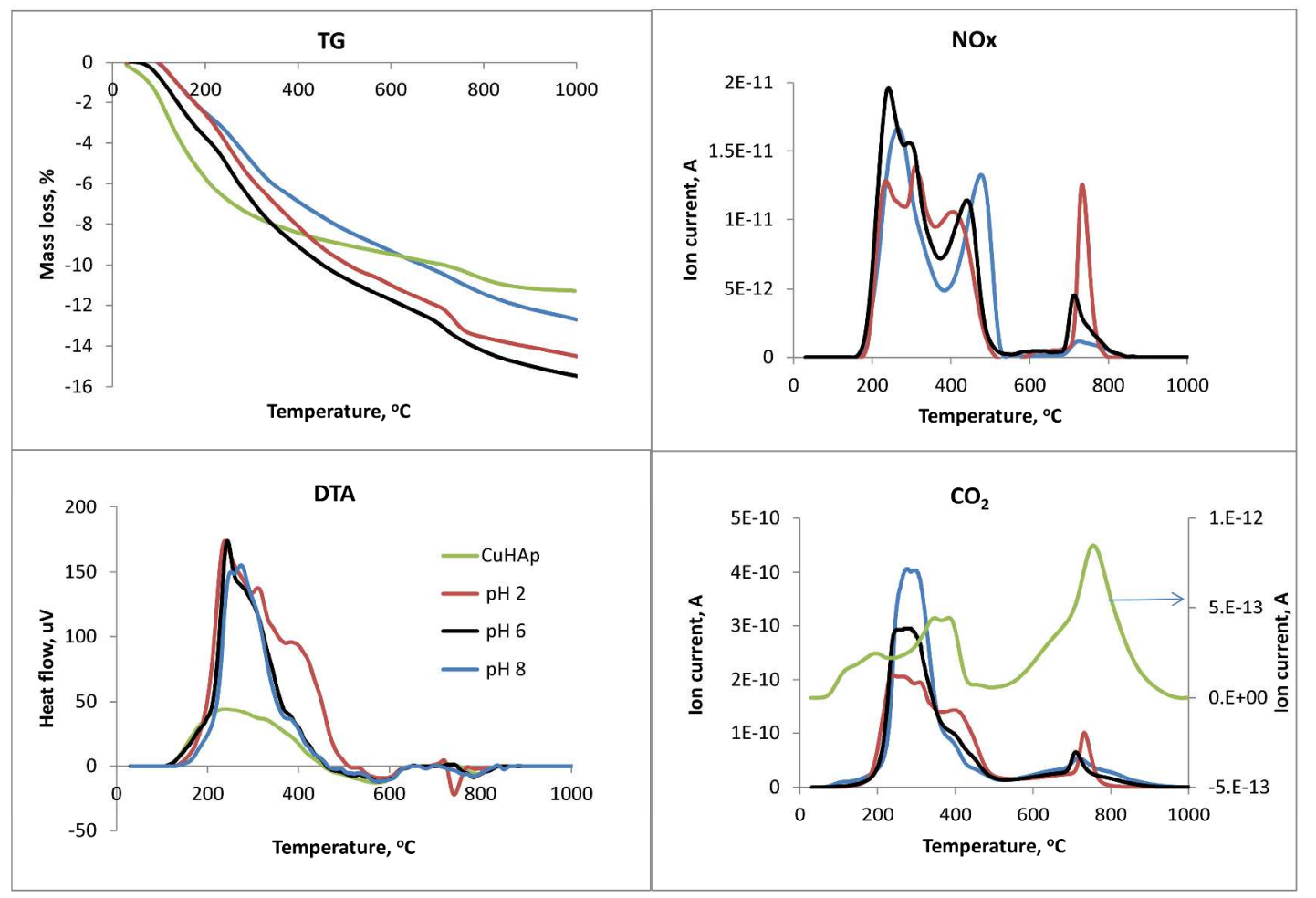

Fig. 6. DTA and mass loss curves of CuHAp and the samples after sorption experiment in 0.02 M O-Ph-L-Ser solutions at $\mathrm{pH}$ 2, 6 and 8.

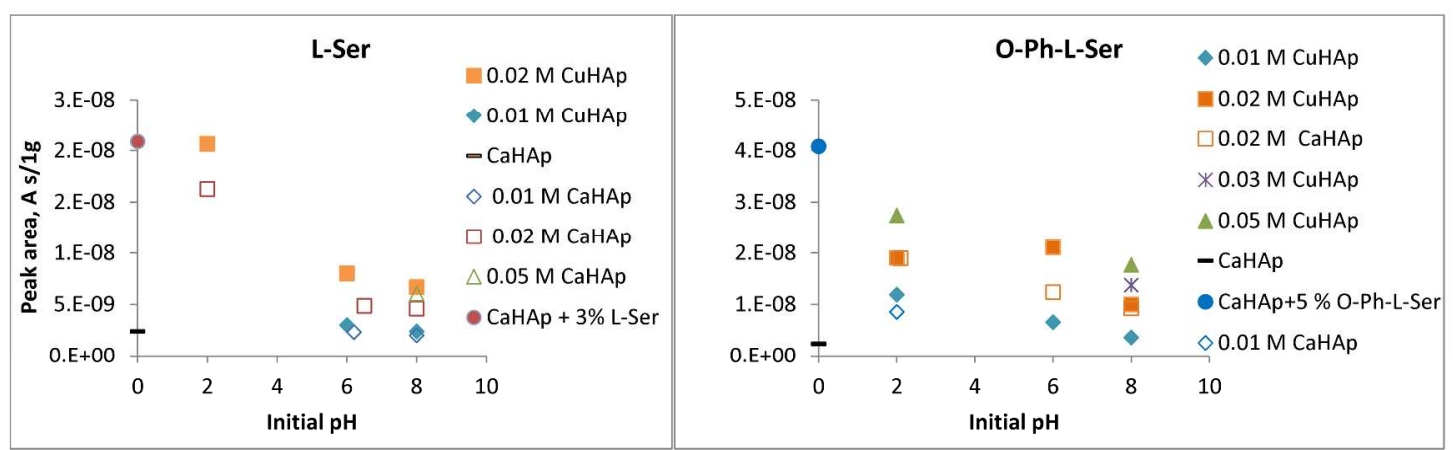

Fig. 7. The peak area of $\mathrm{NO}_{\mathrm{x}}$ evolvement from samples after L-Ser and O-Ph-L-Ser sorption experiment at calcination up to $1000{ }^{\circ} \mathrm{C}$. 


\section{Discussion}

To clarify phenomena at the apatite surface when opposed to AA at different $\mathrm{pH}$ in aqueous medium, the behaviour of both components must be taken into consideration:

1) The apatite surface properties, which depend on cations/P mole ratio and chemical composition and on the medium $\mathrm{pH}[23-25]$.

2) The ionization state of AA, which is strongly dependent on the medium acidity [26].

It is found that for the initial $\mathrm{pH}$ range 4-10, the final $\mathrm{pH}$ values of apatite water suspensions are close to the $\mathrm{pH}_{\mathrm{PZC}}$, which is the $\mathrm{pH}$ value where the surface charge is equal to zero, namely, the $\mathrm{pH}$ at which the charge due to the positive surface groups is equal to negative ones [27]. For the CaHAp and CuHAp used in the study $\mathrm{pH}_{\mathrm{PZC}}$ were found to be 6.46 and 6.82 , respectively. Above the $\mathrm{pH}_{\mathrm{PZC}}$ the apatite surface is negatively charged, it is lightly positive at $\mathrm{pH} 6$ and highly positive at $\mathrm{pH} 2$, at which the apatite dissolves easily [28].

L-Ser appears in water solution at $\mathrm{pH} 2$ partly in the form of neutral zwitterion and partly in the form of positively charged cation; at $\mathrm{pH} 6$ as a neutral zwitterion and at $\mathrm{pH} 8$ about $10 \%$ of protons are neutralized and negatively charged $-\mathrm{COO}^{-}$groups are formed according to Scheme 1.

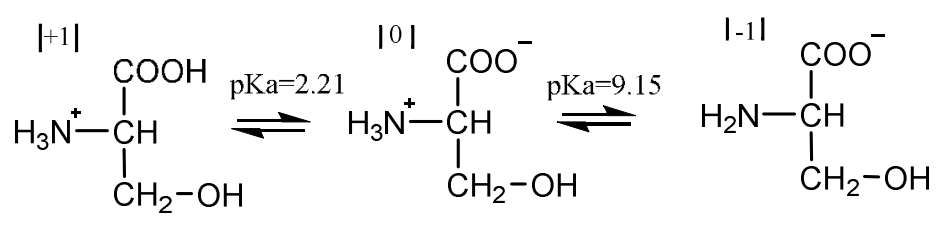

Scheme 1. Ser dissociation scheme [26].

Therefore, as a result of apatite dissolution in acidic medium the $\mathrm{pH}$ of L-Ser solution increases and the rest of $\mathrm{HAp}^{[+]}$is in equilibrium with L-Ser zwitterion, which enables complexation via $\mathrm{COO}^{-}$groups. This explains the $\mathrm{COO}^{-}$vibrations shifts in FTIR spectra (Fig.3). 
Almost no electrostatic tension takes place between HAp and L-Ser in a solution at pH 6-8. LSer can adsorb on hydroxyapatite surface only due to the complexation with surface cations. The complexation constant $\log \mathrm{K}_{\mathrm{f}}$ of $\mathrm{L}-\mathrm{Ser}$ is 1.43 and 7.90 for $\mathrm{Ca}^{2+}$ and $\mathrm{Cu}^{2+}$, respectively [29]. The higher $\log \mathrm{K}_{\mathrm{f}}$ of $\mathrm{Cu}^{2+}$ explains the much higher $\mathrm{Cu}$ release in comparison with $\mathrm{Ca}$ in sorption experiments.

The changes in HAp IR spectra (appearance of a peak at $1546 \mathrm{~cm}^{-1}$, Fig. 3), related to the $\mathrm{COO}^{-}$group complexation with $\mathrm{Ca}^{2+}$ sites at $\mathrm{HAp}$ surface, in contrast with the unchanged IR spectra of CuHAp, as well as the high level of $\mathrm{Cu}^{2+}$ ions release, support the hypothesis of the formation of soluble L-Ser-Cu complex.

The higher organic matter content in the samples after sorption experiments at lower $\mathrm{pH}$ values (Fig. 7) can be explained by higher positive surface charge of apatite and, accordingly, higher electrostatic tension in this case.

O-Ph-L-Ser does not form a typical $\mathrm{COO}^{-}-\mathrm{NH}_{3}{ }^{+}$zwitterion in water. Instead, one of the two phosphate-bound protons dissociates upon dissolution of the crystalline O-Ph-L-Ser in water to form a different $\mathrm{HPO}_{4}{ }^{-}-\mathrm{NH}_{3}{ }^{+}$zwitterion. The three consecutive dissociation steps correspond to the $\mathrm{COOH}, \mathrm{HPO}_{4}{ }^{-}$, and $\mathrm{NH}_{3}{ }^{+}$dissociation. Therefore, at $\mathrm{pH} 2$ in O-Ph-L-Ser solution dominates monobasic acidic form, at $\mathrm{pH} 6$ there is a mixture of negative mono- and dibasic $-\mathrm{OPO}_{3} \mathrm{H}^{-}$ zwitterion and at $\mathrm{pH} 8$ dibasic $-\mathrm{OPO}_{3}{ }^{2-}$ zwitterion (Scheme 2). 


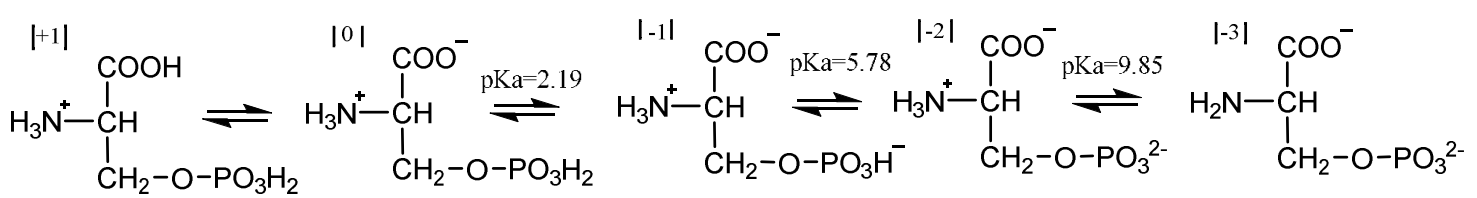

NA<smiles>NC(COP(=O)(O)O)C(=O)O</smiles>

MZ

DB

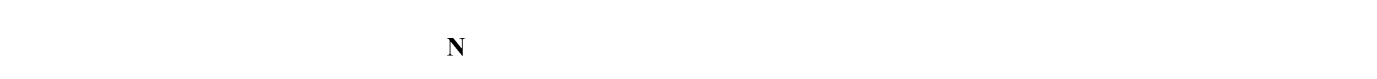

Scheme 2. P-Ser dissociation scheme [30].

Consequently, apatite dissolves in $\mathrm{O}-\mathrm{Ph}-\mathrm{L}-\mathrm{Ser}$ solution at $\mathrm{pH} 2$ and a big amount of cations are released leading to the $\mathrm{pH}$ increase. $\mathrm{Ca}$ and $\mathrm{Cu}$ leaching into the solution is not only the consequence of the initial low $\mathrm{pH}$ value of the solution, but also results from the formation of $\mathrm{Cu}^{2+}$ and $\mathrm{Ca}^{2+} \mathrm{O}-\mathrm{Ph}-\mathrm{L}-\mathrm{Ser}$ soluble complexes. Between the non-dissolved apatite and L-Ser negatively charged zwitterion electric tension exists, that results in the highest content of organic matter in the samples after sorption experiment at initial $\mathrm{pH} 2$, detected by TA (Fig. 7) and more visible changes in IR spectra (Fig. 3 and 4).

The electric tension and the stability of Ca-P-Ser soluble complexes decrease at higher $\mathrm{pH}$ values, when the stability of $\mathrm{Cu}$ complexes increases $[30,31]$. The increased stability of O-Ph-LSer - $\mathrm{Cu}$ complexes, in turn, explains the increase in $\mathrm{Cu}$ release at $\mathrm{pH} 8$.

Therefore, the cations release from apatite takes place as a consequence of apatite dissolution at $\mathrm{pH}<5$ and also due to the formation of soluble complexes with amino acids. At higher $\mathrm{pH}$ values the main reason of the cations release is the formation of complexes, particularly with $\mathrm{Cu}^{2+}$ ions. In acidic medium and in the case of O-Ph-L-Ser, the effective site for bonding of metal ions is the phosphate group, which significance decreases with increasing $\mathrm{pH}$ as the effectiveness of the carboxyl and amine groups is raised [32]. 


\section{Conclusions}

The processes occurring on the apatite surface when treated by L-Ser and O-Ph-L-Ser aqueous solutions were clarified. To understand the adsorption phenomena, it is necessary to take into consideration the ionic state of the amino acid and that of the apatite surface which are tightly correlated with the $\mathrm{pH}$ value of the solutions. In acidic solutions the dominant process is apatite dissolution. At the same time, due to the electrostatic attraction, negatively charged ions of the amino acid are adsorbed on the apatite surface. The amino acids interaction with apatite at $\mathrm{pH}>$ 6 is mainly related to its complexation with cations of apatite structure. In accordance with the higher stability of soluble $\mathrm{Cu}^{2+}$ complexes, the relative release of $\mathrm{Cu}^{2+}$ ions from $\mathrm{Cu}$ substituted apatite is higher than that of $\mathrm{Ca}^{2+}$ ions in both amino acid solutions. Thereby, if the $\mathrm{Cu}$ release increases with the $\mathrm{pH}$ and $\mathrm{O}-\mathrm{Ph}-\mathrm{L}-\mathrm{Ser}$ concentration increase, the Ca release drops remarkably at pH 8 in the case of P-Ser amount 1 mmol per 300 mg HAp. Impact of pH is less important for $\mathrm{Cu}$ release in L-Ser solution, the effect is more visible for Ca release in both AA solutions.

\section{Acknowledgments}

The current research was supported by the Estonian Ministry of Education and Research (Institutional research funding IUT33-19), CNRS, UPMC and TTU.

The authors thank Dr. Jamal Moussa for helpful discussions. 


\section{References}

1. Šupová M (2015) Substituted hydroxyapatites for biomedical applications: A review. Ceram Int 41:9203-9231

2. El Rhilassi A, Mourabet M, Bennani-Ziatni M, El Hamri R, Taitai A (2016) Interaction of some essential amino acids with synthesized poorly crystalline hydroxyapatite. J Saudi Chem Soc 20:632-640

3. Errassifi F, Menbaoui A, Autefage H, Benaziz L, Ouizat S, Santran V, Sarda S, Lebugle A, Combes C, Barroug A, Sfihi H, Rey C (2010) In: Advances in bioceramics and biotechnologies. John Wiley \& Sons Inc, pp 159-174

4. Ozhukil Kollath V, Van den Broeck F, Fehér K, Martins JC, Luyten J, Traina K, Mullens S, Cloots R (2015) A modular approach to study protein adsorption on surface modified hydroxyapatite. Chem-Eur J 21: 10497-10505

5. Errassifi F, Sarda S, Barroug A, Legrouri A, Sfihi H, Rey C (2014) Infrared, Raman and NMR investigations of risedronate adsorption on nanocrystalline apatites. J Coll Interface Sci 420:101-111

6. Spanos N, Klepetsanis PG, Koutsoukos PG (2001) Model Studies on the Interaction of Amino Acids with Biominerals: The Effect of L-Serine at the Hydroxyapatite-Water Interface. J Coll Interface Sci 236:260-265

7. Benaziz L, Barroug A, Legrouri A, Rey C, Lebugle A (2001) Adsorption of O-Phospho-LSerine and L-Serine onto Poorly Crystalline Apatite. J Coll Interface Sci 238:48-53 
8. Skartsila K, Spanos N (2012) Adsorption monitoring of phospho-1-serine on hydroxyapatite. Colloid Polym Sci 290: 731-739

9. Spanos N, Koutsoukos PG (2001) Model Studies of the Effect of Orthophospho-L-serine on Biological Mineralization. Langmuir 17:866-872

10. Misra DN (1997) Interaction of ortho-Phospho-1-serine with Hydroxyapatite: Formation of a Surface Complex. J Coll Interface Sci 194:249-255

11. Festa RA, Thiele DJ (2011) Copper: An essential metal in biology. Curr Biol 21:877-883

12. Clavadetscher J, Hoffmann S, Lilienkampf A, Mackay L, Yusop RM, Rider SA, Mullins JJ, Bradley M (2016) Copper Catalysis in Living Systems and In Situ Drug Synthesis. Angew Chem Int Ed Engl 55:15662-15666

13. Chemler SR (2015) Copper catalysis in organic synthesis. Beilstein J Org Chem 11:22522253.

14. Rodriguez-Carvajal J (2001) Resent developments of the program FULLPROF. Commission on Powder Diffraction Newsletter 26:12-19.

15. Elliot JC (1994) Structure and chemistry of the apatites and other calcium orthophosphates. Elsevier, Amsterdam

16. Frank-Kamenetskaya OV (2008) In: Krivovichev SV (eds) Minerals as advanced materials I. Springer, Berlin Heidelberg, pp 241-252 
17. Frank-Kamenetskaya O, Golubtsov V, Pikhur O, Zorina M, Plotkina YV (2004) Nonstoichiometric apatite of the human dental hard tissues (the age alterations). Zap Vseross Mineral O-va 5:120-130

18. Jarmelo S, Reva I, Carey P, Fausto R (2007) Infrared and Raman spectroscopic characterization of the hydrogen-bonding network in L-serine crystal. Vib Spectrosc 43:395-404

19. Lee WH, Loo CY, Zavgorodniy AV, Rohanizadeh R (2013) High protein adsorptive capacity of amino acid-functionalized hydroxyapatite. J Biomed Mater Res Part A 101:873883

20. Fleet ME (2014) Carbonated Hydroxyapatite: Materials, Synthesis, and Applications. Pan Stanford Publishing, Singapore

21. Gonzalez-McQuire R, Chane-Ching J-Y, Vignaud E, Lebugle A, Mann S (2004) Synthesis and characterization of amino acid-functionalized hydroxyapatite nanorods. J Mater Chem $14: 2277-2281$

22. Othmani M, Aissa A, Grelard A, Das RK, Oda R, Debbabi M (2016) Synthesis and characterization of hydroxyapatite-based nanocomposites by the functionalization of hydroxyapatite nanoparticles with phosphonic acids. Colloids Surf A 508:336-344

23. Tsuchida T, Kubo J, Yoshioka T, Sakuma S, Takeguchi T, Ueda W (2008) Reaction of ethanol over hydroxyapatite affected by Ca/P ratio of catalyst. J Catal 259:183-189

24. Bengtsson Å, Sjöberg S (2009) Surface complexation and proton-promoted dissolution in aqueous apatite systems. Pure Appl Chem 81:1569-1584 
25. Garcia Rodenas L, Palacios J. M, Apella MC, Morando PJ, Blesa MA (2005) Surface properties of various powdered hydroxyapatites. J Coll Interface Sci 290:145-154

26. Fleck M, Petrosyan AM (2014) Salts of amino acids: crystallization, structure and properties. Springer

27. Smičiklas I, Milonjić S, Pfendt P, Raičević S (2000) The point of zero charge and sorption of cadmium (II) and strontium (II) ions on synthetic hydroxyapatite. Sep Purif Technol 18: $185-194$

28. Dorozhkin SV (2012) Dissolution mechanism of calcium apatites in acids: A review of literature. World journal of methodology 2:1-17

29. In Standard Reference Database 46, NIST Critically Selected Stability Constants of Metal Complexes Database Version 8.0

30. Śmiechowski M (2010) Theoretical pKa prediction of O-phosphoserine in aqueous solution. Chem Phys Lett 501:123-129

31. Zachariou M, Traverso I, Spiccia L, Hearn MT (1996) Potentiometric Investigations into the Acid- Base and Metal Ion Binding Properties of Immobilized Metal Ion Affinity Chromatographic (IMAC) Adsorbents. J Phys Chem 100:12680-12690

32. Jastrzab R, Lomozik L (2009) Effectiveness of Phosphate Groups in Noncovalent Interactions in Binary Adenosine Nucleotides/Phosphoserine Aqueous Systems. J Solution Chem 38:35-46 


\section{Supplementary materials}

Table S1. Unit cell parameters and particles size of apatite samples before and after sorption experiments in 0.02 M O-Ph-L-Ser and L-Ser solution.

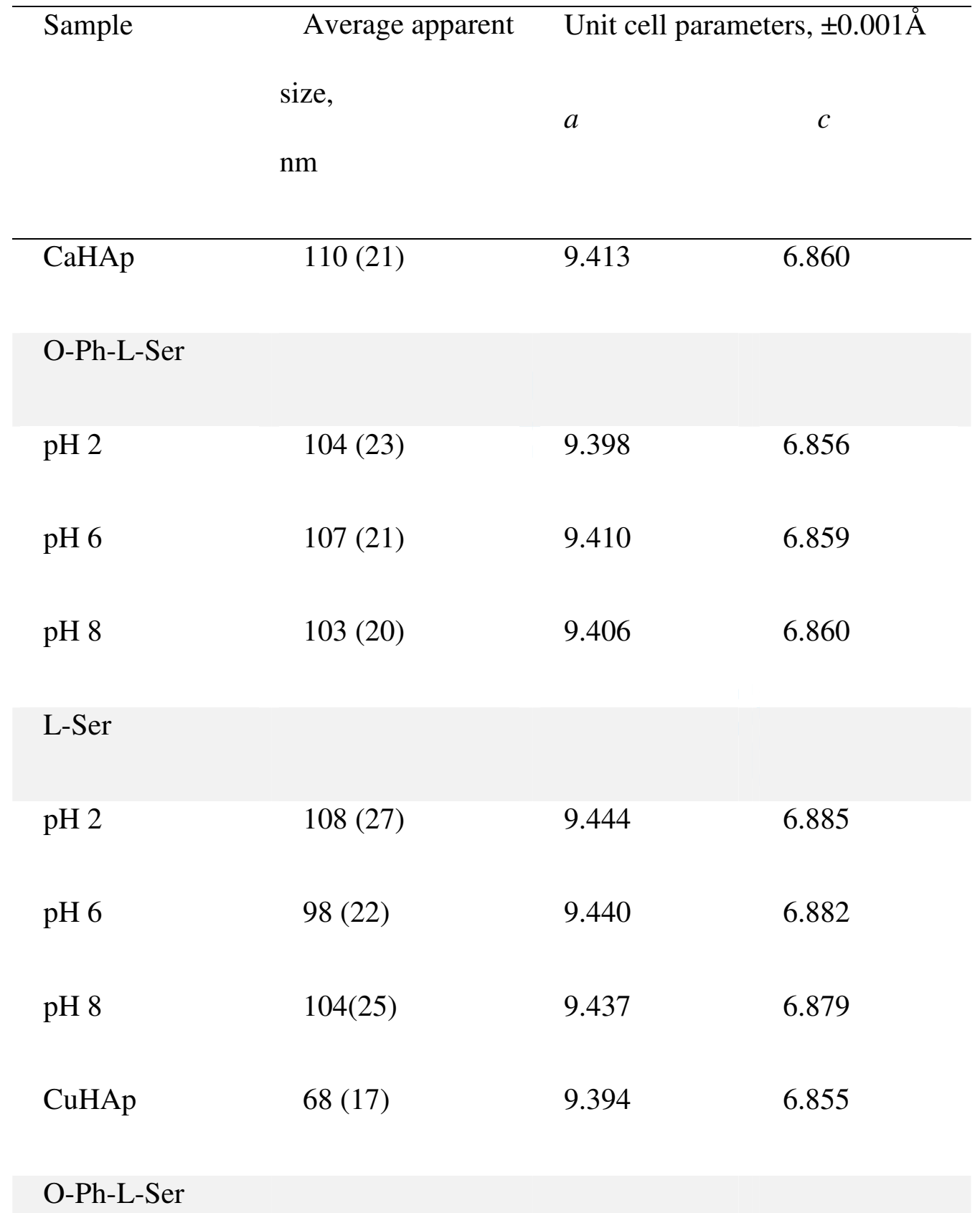




\begin{tabular}{cccc}
\hline $\mathrm{pH} 2$ & $62(15)$ & 9.392 & 6.852 \\
$\mathrm{pH} 6$ & $65(15)$ & 9.396 & 6.859 \\
$\mathrm{pH} 8$ & $68(16)$ & 9.390 & 6.854 \\
$\mathrm{~L}-\mathrm{Ser}$ & & & \\
$\mathrm{pH} 6$ & $70(19)$ & 9.420 & 6.871 \\
$\mathrm{pH} 8$ & $76(20)$ & 9.431 & 6.878 \\
\hline
\end{tabular}




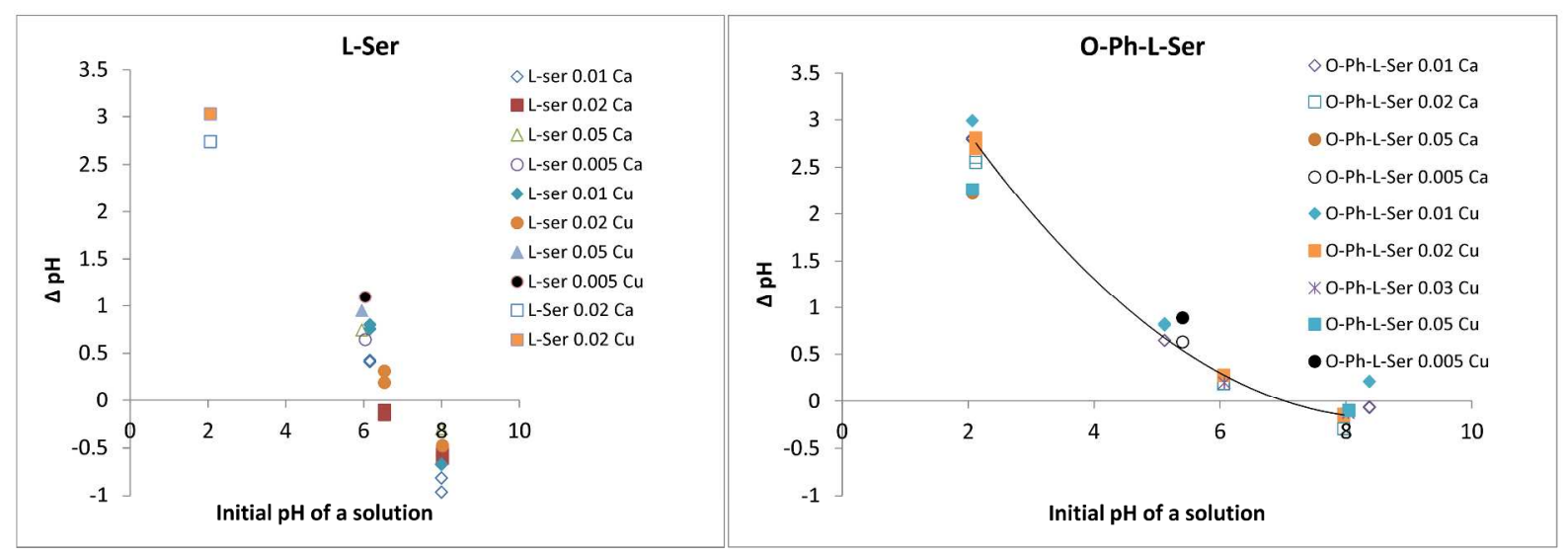

Figure S1. Change of the solution $\mathrm{pH}$ as a result of contact with apatite. $\Delta \mathrm{pH}=\mathrm{pH}_{\text {initial }}-\mathrm{pH}_{\text {final }}$

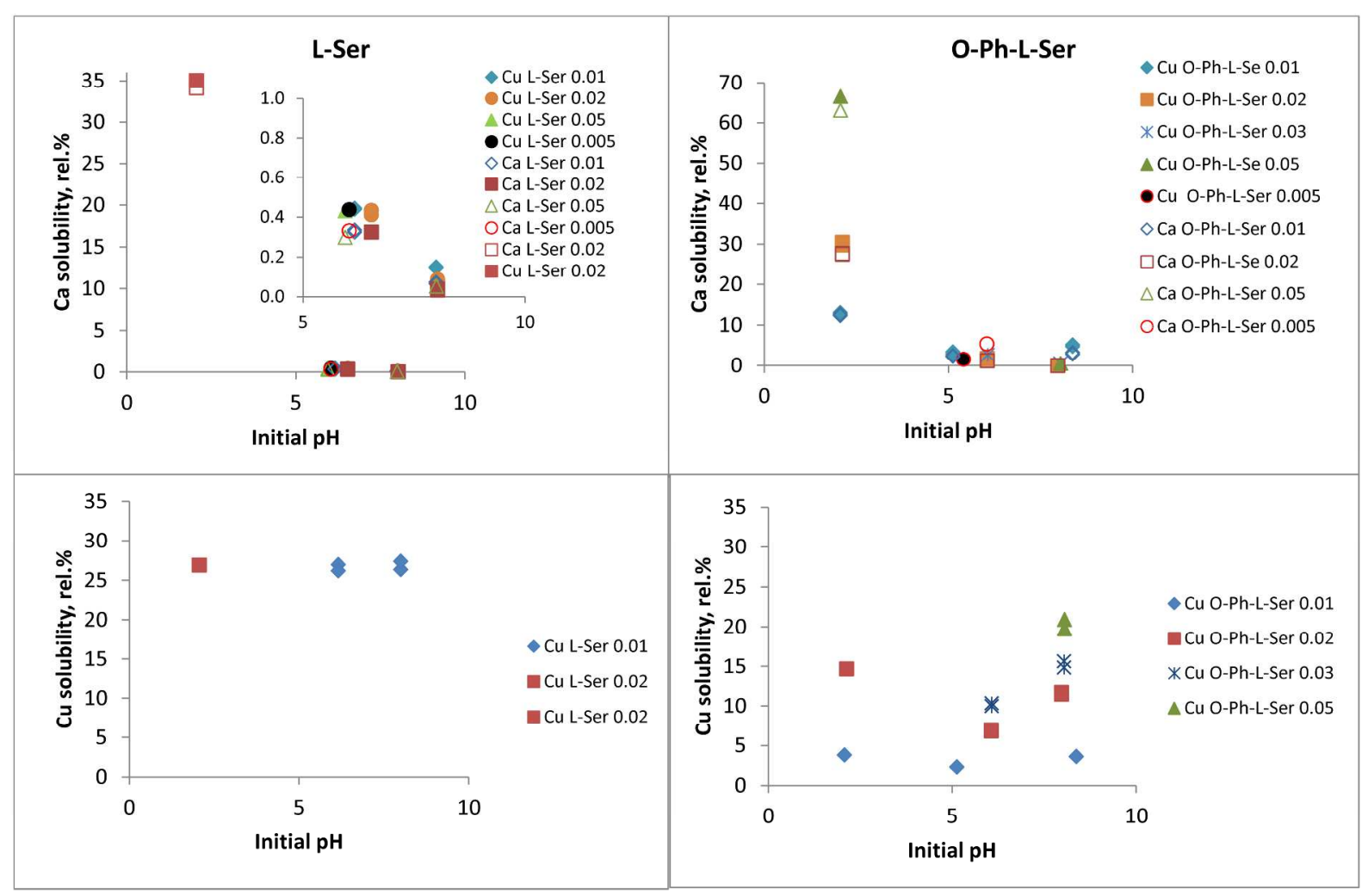

Figure S2. $\mathrm{Ca}$ and $\mathrm{Cu}$ relative solubility in L-Ser and O-Ph-L-Ser solutions depending on solution initial $\mathrm{pH}$. 


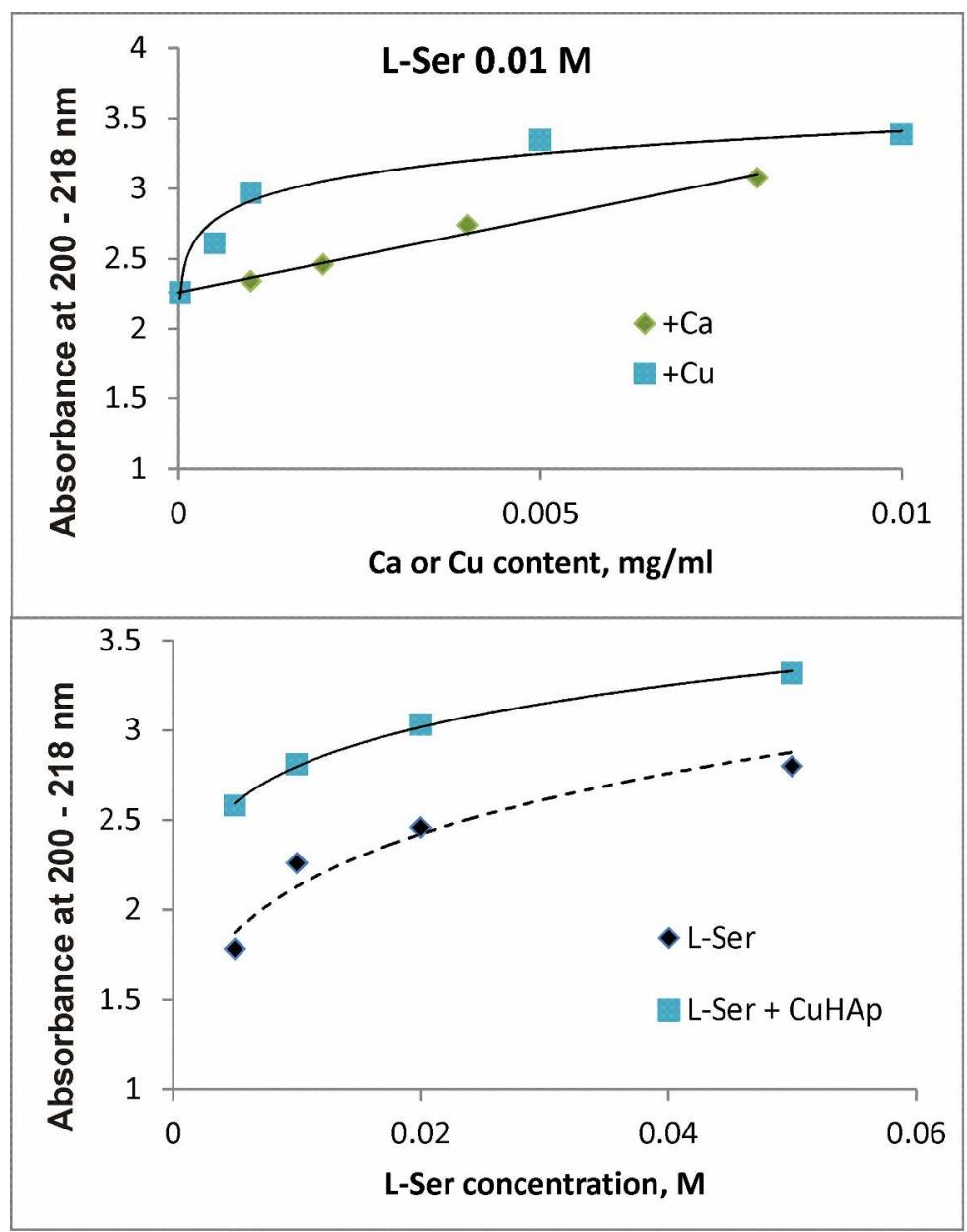

Figure S3. UV absorption intensity at 200-210 nm a) for 0.01 M L-Ser solution with different Ca or $\mathrm{Cu}$ content; b) depending on L-Ser concentration before and after reaction with CuHAp. 


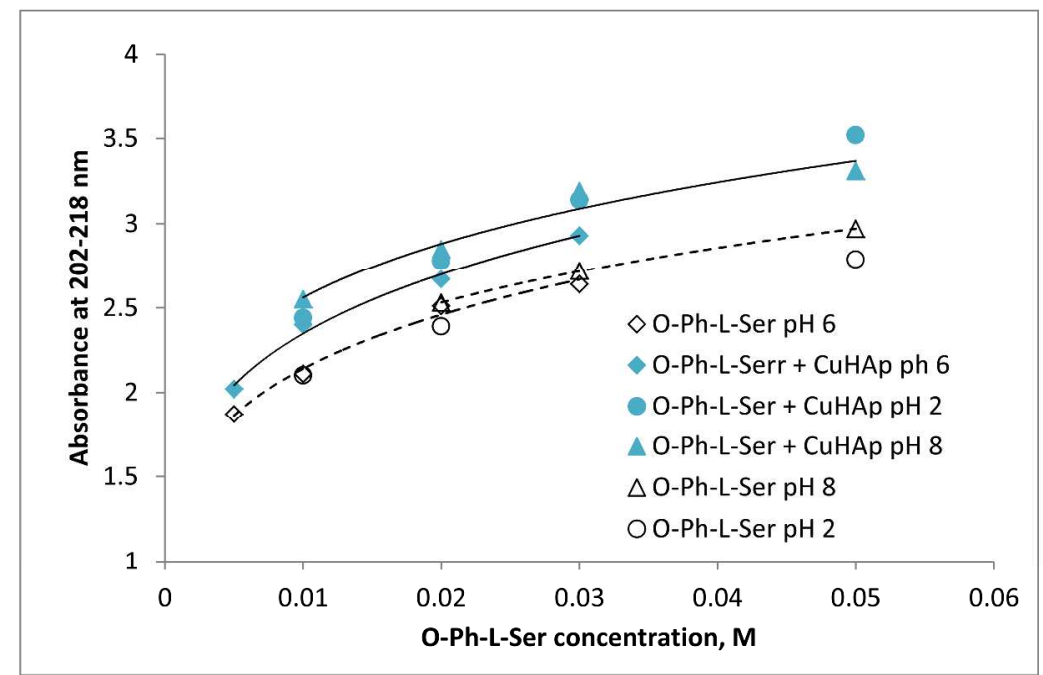

Figure S4. UV absorption intensity at 200-210 nm depending on O-Ph-L-Ser concentration and $\mathrm{pH}$ before and after reaction with CuHAp.

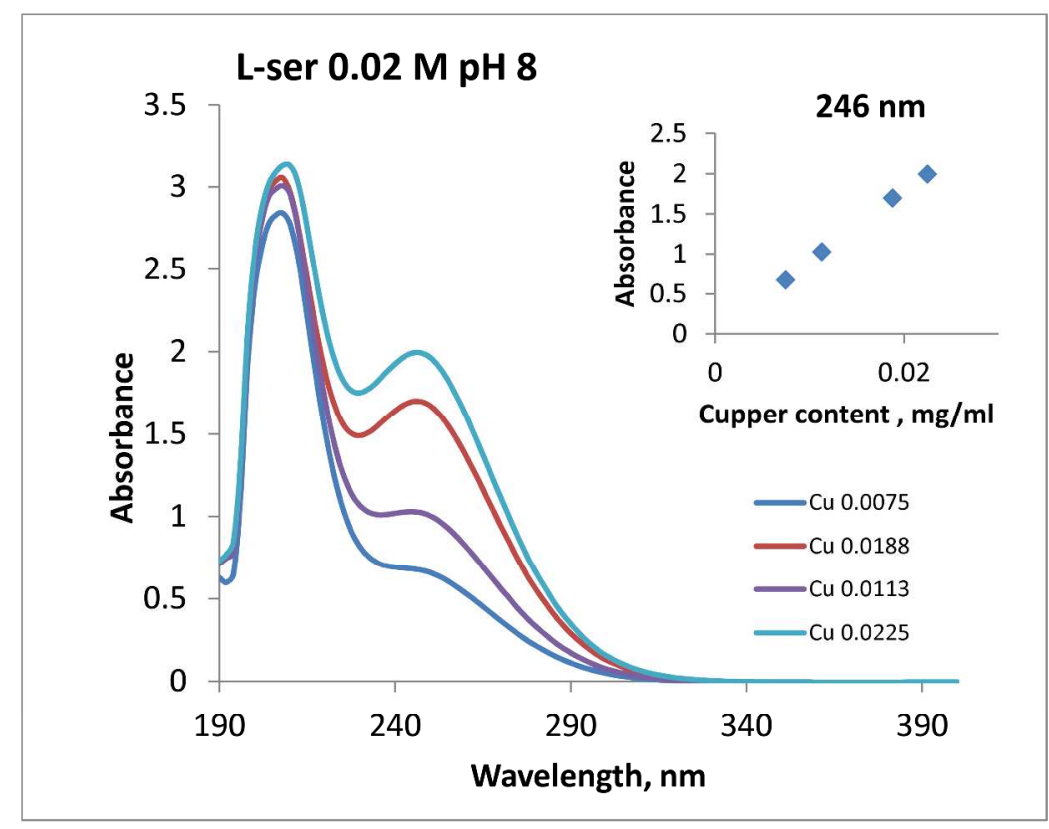

Figure S5. UV absorbance of L-Ser $0.02 \mathrm{M}$ solution at $\mathrm{pH} 8$ with different content of $\mathrm{Cu}^{2+}$ ions. 


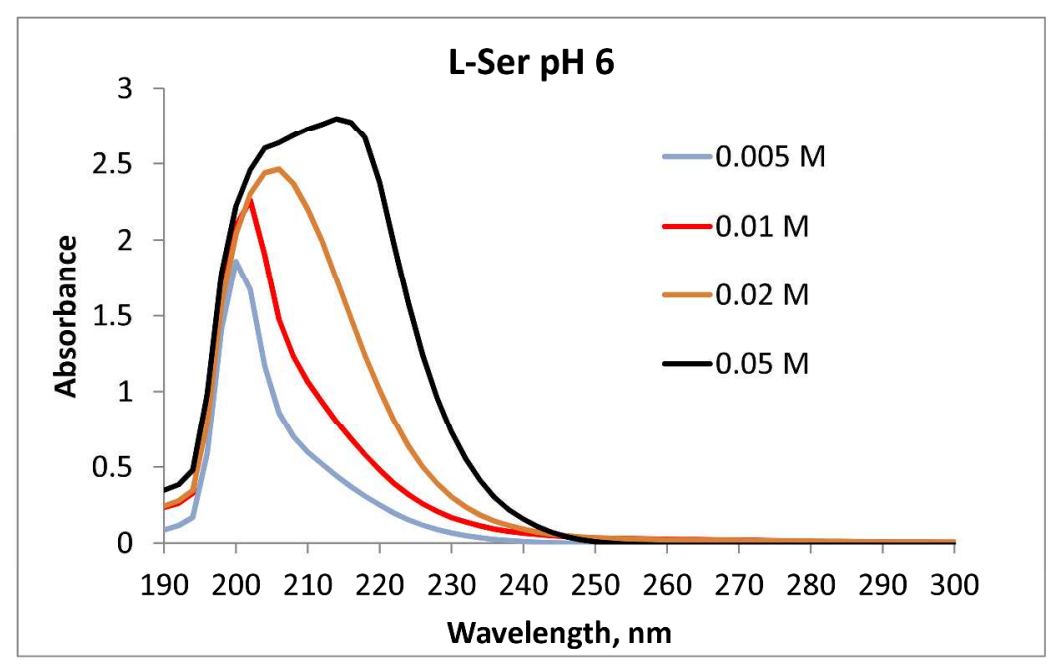

Figure S6. UV absorption spectra of L-Ser solutions at pH 6. 


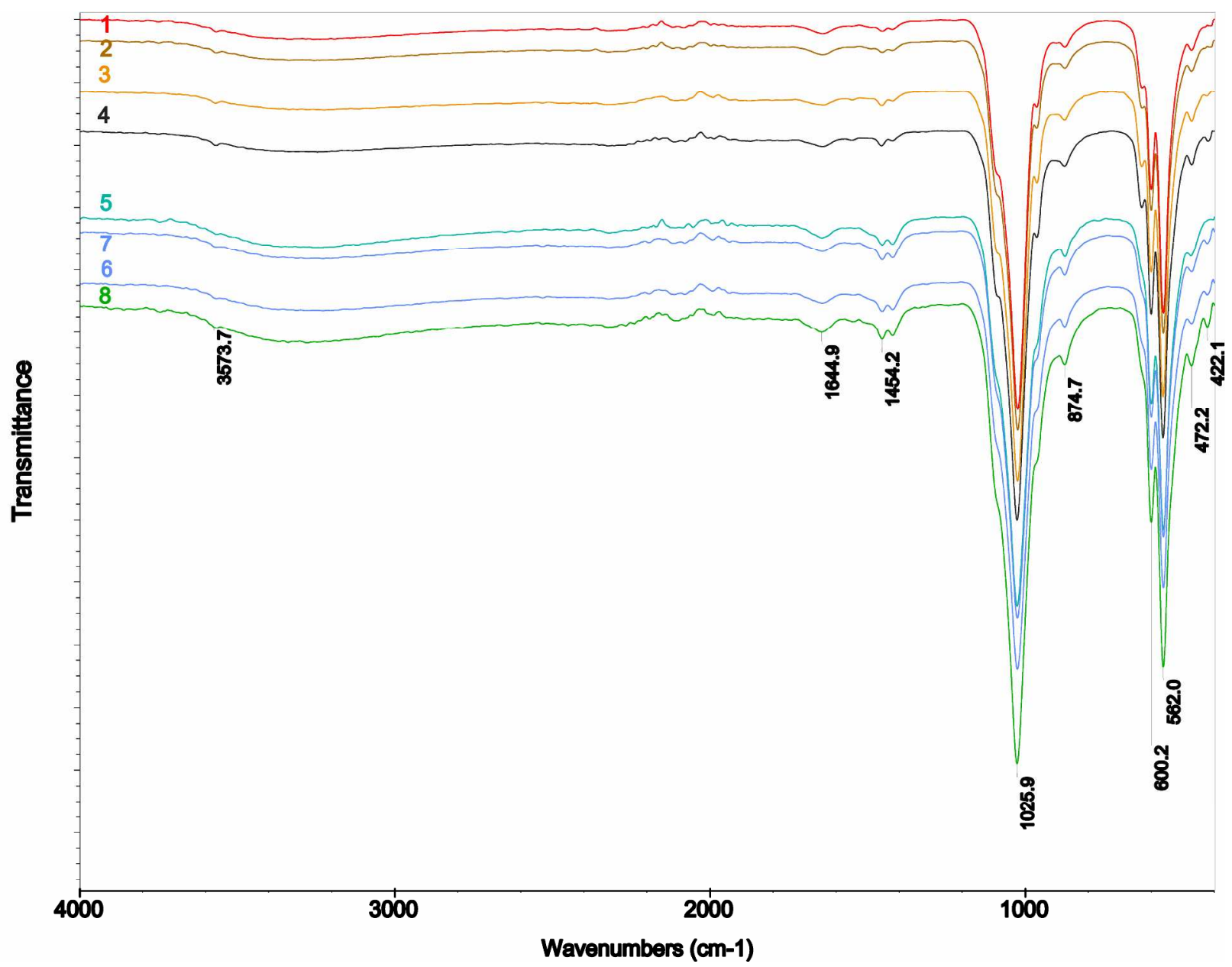

Figure S7. IR spectra of : 1 - CaHAp; 2 - CaHAp after treatment in water at $\mathrm{pH}$ 8, 3 - CaHAp after treatment at $\mathrm{pH}$ 6; 4 - CaHAp after treatment at $\mathrm{pH}$ 2; 5 - CuHAp; 6-CuHAp after treatment in water at $\mathrm{pH} \mathrm{8,7-CuHAp}$ after treatment at $\mathrm{pH} \mathrm{6;8-CuHAp} \mathrm{after} \mathrm{treatment} \mathrm{at} \mathrm{pH}$ 2. 